\title{
Autonomic neuropathy in acute intermittent porphyria
}

\author{
AC YEUNG LAIWAH, GJA MACPHEE, P BOYLE, MR MOORE, A GOLDBERG
}

From the University Department of Medicine, Western Infirmary, Glasgow, Scotland

SUMMARY Autonomic function was assessed in subjects with acute intermittent porphyria and age- and sex-matched controls using five different bedside tests of cardiovascular reflexes. During the acute attack both parasympathetic and sympathetic tests were impaired, but subsequently improved during remission. Early parasympathetic dysfunction was also detected during remission and in latent asymptomatic acute intermittent porphyria.

Acute intermittent porphyria is an autosomal dominant inborn error of metabolism characterised by a partial deficiency in the activity of the haem biosynthetic enzyme, porphobilinogen deaminase (PBG). Consequently the porphyrin precursors delta-aminolaevulinic acid (ALA) and porphobilinogen (PBG) accumulate in blood and are excreted in excessive amounts in the urine..$^{2}$

The clinical manifestations of acute intermittent porphyria have been attributed to a widespread neurological dysfunction caused by the block in haem biosynthesis. ${ }^{34}$ Abdominal pain is the commonest and often the most troublesome symptom which occurs in more than $90 \%$ of cases. ${ }^{5}$ It has been explained on the basis of splanchnic autonomic dysfunction, thus providing a mechanism for the intestinal dilatation and stasis occasionally noted radiologically and at laparotomy in patients suffering from an acute attack. ${ }^{6}$ Indeed, many of the accompanying features of an acute attack are suggestive of autonomic neuropathy; namely, the inappropriate sinus tachycardia, labile hypertension, postural hypotension, excessive sweating, severe vomiting, constipation and occasional diarrhoea and sphincteric bladder problems. ${ }^{58}$ Ridley et al have reported that tachycardia invariably preceded the development of peripheral neuropathy and respiratory paralysis, and they postulated that the tachycardia of porphyria might be due to autonomic cardioneuropathy. ${ }^{8}$ The transient and labile hypertension which commonly accompanies the acute attack has also been given a neurogenic explanation follow-

Address for reprint requests: Dr AC Yeung Laiwah, Department of Medicine, Gardiner Institute, Western Infirmary, Glasgow G11 6NT, UK.

Received 22 January 1985. Accepted 2 March 1985 ing damage to the vagal nerves from the underlying disease. ${ }^{y}$

The development of simple non-invasive tests of cardiovascular reflex function has enabled objective assessment of autonomic neuropathy to be made in a more systematic way than hitherto possible. ${ }^{1011}$ We therefore studied autonomic function in patients with acute intermittent porphyria by using three tests that reflect cardiac parasympathetic integrity and two tests which give abnormal results with sympathetic nerve damage.

\section{Patients and methods}

Four groups of subjects were studied, the individuals selected being less than 45 years of age. Group I consisted of 28 normal healthy subjects, age- and sex-matched with patients with acute intermittent porphyria in groups II, III and IV. Group II comprised eight patients admitted to hospital during an acute attack of acute intermittent porphyria prior to receiving any form of drug treatment. Six of these patients were subsequently retested while in remission and were also included in group III. In group III there were 14 asymptomatic patients with acute intermittent porphyria in remission, their last attack having occurred at least 6 months prior to autonomic testing (range 6 months -10 years). In group IV there were 10 latent cases of acute intermittent porphyria identified after screening relatives of known symptomatic cases. The latent cases denied ever having had any symptoms of acute porphyria, and they belonged to different kindreds. None of the subjects tested was taking any drugs that are known to interfere with autonomic tests. They all had a normal haemoglobin, random blood sugar and blood lead levels. In all symptomatic cases the diag- 
nosis of acute intermittent porphyria was made on the basis of excess urinary excretion of ALA, PBG and uroporphyrins, and confirmed by the measurement of the haem enzymes ALA synthase and PBG deaminase in the peripheral leucocytes and erythrocytes respectively. In latent cases in which urinary excretion of porphyrin precursors and porphyrins are not necessarily elevated the diagnosis depended on the measurements of ALA synthase and PBG deaminase activity. ${ }^{12}$ Urinary PBG and porphyrins were measured by the methods of Moore $^{13}$ and ALA by the method of Mauzerall and Granick. ${ }^{14}$ ALA synthase and PBG deaminase activity were measured by methods listed by Moore et al. ${ }^{\text {is }}$

The three parasympathetic tests performed consisted of heart rate responses to the Valsalva manoeuvre and to standing from a lying position, and beat-to-beat variation in heart-rate with respiration. The two tests of sympathetic function were blood pressure response to sustained isometric hand-grip and postural drop in blood pressure upon standing. "

1 Valsalva manoeuvre:" The subjects were asked to blow into a tube connected to an aneroid manometer (Cape Engineering Co Ltd, Warwick, England) with their nostrils closed and to hold their breath at a pressure of $50 \mathrm{mmHg}$ for 15 seconds while a continuous electrocardiogram was recorded. The Valsalva ratio was calculated from the ratio of the longest $R-R$ interval after the manoeuvre (reflecting the rebound bradycardia) to the shortest R-R interval during the manoeuvre (reflecting the tachycardia during strain).

2 Heart-rate response to standing: ${ }^{16}$ After lying down in a relaxed state for five minutes, the subject was asked to stand up gently, unaided, and to remain standing for a further two minutes. A continuous ECG tracing was recorded for the period starting a few beats before until about 60 beats after standing. The R-R intervals were then measured with a ruler. The heart-rate response was expressed as the ratio of the longest $R-R$ interval around the 30th beat to the shortest $R-R$ interval around the 15 th beat after standing (the 30:15 ratio).

3 Heart rate variation during deep breathing: ${ }^{17}$ The patient, resting supine, was instructed to breathe deeply at the rate of six breaths per minute (timed 5 seconds in and 5 seconds out) while an electrocardiogram was recorded. The minimum and maximum $R-R$ intervals during each breathing cycle were measured with a ruler and converted to the equivalent number of beats per minute. The final result was taken as the mean of the difference between the maximal and minimal heart rates for three breathing cycles.

4 Sustained hand-grip test: ${ }^{\prime \prime}$ First the maximum voluntary contraction (MVC) for the dominant hand was determined using a handgrip dynamometer (Tephcotronics Ltd, Edinburgh). The subject was then encouraged to maintain his handgrip steadily at only $30 \%$ of that MVC for as long as possible up to a maximum of five minutes. Blood pressure was measured by means of a London School of Tropical Medicine Sphygmomanometer (Rose-Box) on the non-exercising arm with recordings made three times at rest and at one-minute intervals during applied grip. The response to the test was taken as the difference in diastolic blood pressure (phase 5) between the mean of the three resting measurements and the last reading before release of handgrip.

5 Postural drop in blood pressure:" The blood pressure of the subject was recorded after ten minutes rest while lying down and again, within 30 to 60 seconds, after standing up. The difference between the systolic blood pressure measured when lying and when standing was taken as the postural fall in blood pressure.

\section{Statistical analysis}

The significance of differences between the mean values obtained in groups I, II, III and IV was examined by Analysis of Variance. When this was found to be significant differences between individual group means were examined, in a standard manner, by follow-up $t$ tests.

\section{Results}

Table 1 gives the clinical details of patients in group II who were in an acute attack at the time of autonomic testing. They all had severe abdominal pain. Six of the eight patients had detectable motor weakness affecting the limbs, especially the extensor muscles of the wrists. Those with motor involvement had a higher basal heart rate (range 84-119 beats/ min) than normal (range 64-78).

All the subjects managed to perform the autonomic tests satisfactorily except for four of the eight patients in group II who had difficulty in sustaining the handgrip (test 4) as described. The test was accordingly modified in that these four patients were encouraged to sustain near maximum handgrip for at least 15 seconds before their blood pressure was measured.

The mean values $( \pm S D)$ for the five tests of autonomic function are presented in table 2 . The three tests of parasympathetic cadiovascular reflex: Valsalva manoeuvre, heart-rate response to standing and heart-rate variation during deep breathing, and one of the two tests of sympathetic function, the blood pressure response to sustained hand-grip were abnormal for group II as compared to normal con- 
Table 1 Clinical details of individual porphyric patients in group II

\begin{tabular}{|c|c|c|c|c|c|c|c|c|c|c|c|}
\hline \multirow[t]{2}{*}{ Patients } & \multirow[t]{2}{*}{ Sex } & \multirow[t]{2}{*}{ Age (yr) } & \multirow{2}{*}{\multicolumn{2}{|c|}{$\begin{array}{l}\text { Time since first Resting heart } \\
\text { acute attack rate beats } \\
(y r)\end{array}$}} & \multirow{2}{*}{$\begin{array}{l}\text { Basal blood } \\
\text { pressure } \\
(\mathrm{mm} \mathbf{H g})\end{array}$} & \multicolumn{6}{|c|}{ Clinical features of acute attack } \\
\hline & & & & & & $\begin{array}{l}\text { Abdon } \\
\text { pain } \\
\text { (0 to }\end{array}$ & Vomiting & & $\begin{array}{c}\text { onstipation Excessive } \\
\text { sweating }\end{array}$ & $\begin{array}{l}\text { Postural } \\
\text { dizziness }\end{array}$ & $\begin{array}{l}\text { Peripheral } \\
\text { motor } \\
\text { weakness }\end{array}$ \\
\hline $\begin{array}{l}\text { JC } \\
\text { JM } \\
\text { CM } \\
\text { HW } \\
\text { EL } \dagger \\
\text { JB } \neq \\
\text { RR } \\
\text { AW }\end{array}$ & $\begin{array}{l}\mathbf{F} \\
\mathbf{F} \\
\mathbf{F} \\
\mathbf{F} \\
\mathbf{F} \\
\mathbf{F} \\
\mathbf{M} \\
\mathbf{M}\end{array}$ & $\begin{array}{l}27 \\
27 \\
20 \\
26 \\
32 \\
28 \\
36 \\
27\end{array}$ & $\begin{array}{l}6 \\
7 \\
3 \\
3 \\
5 \\
4 \\
4 \\
6\end{array}$ & $\begin{array}{r}72 \\
84 \\
119 \\
92 \\
102 \\
94 \\
86 \\
78\end{array}$ & $\begin{array}{l}110 / 65 \\
120 / 80 \\
140 / 100 \\
130 / 90 \\
160 / 105 \\
155 / 95 \\
145 / 85 \\
130 / 80\end{array}$ & $\begin{array}{l}+++ \\
+++ \\
+++ \\
++ \\
+++ \\
++ \\
+++ \\
++\end{array}$ & $\begin{array}{l}+ \\
- \\
- \\
+ \\
- \\
- \\
-\end{array}$ & $\begin{array}{l}+ \\
+ \\
+ \\
+ \\
+ \\
+ \\
+ \\
+\end{array}$ & $\begin{array}{l}- \\
\overline{+} \\
\overline{-} \\
+ \\
\overline{+} \\
-\end{array}$ & $\begin{array}{l}- \\
- \\
\overline{+} \\
- \\
- \\
- \\
-\end{array}$ & $\begin{array}{l}\text { No } \\
\text { Yes } \\
\text { Yes } \\
\text { Yes } \\
\text { Yes } \\
\text { Yes } \\
\text { Yes } \\
\text { No }\end{array}$ \\
\hline
\end{tabular}

*At the time of autonomic testing.

+Persistent attack lasting more than 2 years.

$\ddagger$ Not retested during remission.

Table 2 Results of autonomic function tests in patients with acute intermittent porphyria

\begin{tabular}{|c|c|c|c|c|c|c|c|c|}
\hline & \multirow{2}{*}{$\begin{array}{l}\text { No of } \\
\text { subjects }\end{array}$} & \multirow[t]{2}{*}{ Age (yr) } & \multirow{2}{*}{$\begin{array}{l}\text { Basal heart rate } \\
\text { (beats/min) }\end{array}$} & \multicolumn{3}{|c|}{ Parasympathetic tests } & \multicolumn{2}{|c|}{ Sympathetic tests } \\
\hline & & & & Valsalva ratio & $\begin{array}{l}\text { Heart rate response } \\
\text { to standing } \\
\text { (30:15 ratio) }\end{array}$ & $\begin{array}{l}\text { Beat-to-beat } \\
\text { variation in heart } \\
(R-R \text { interval) }\end{array}$ & $\begin{array}{l}\text { Sustained } \\
\text { handgrip } \ddagger \\
\text { rate } \\
(\mathrm{mm} \mathrm{Hg})\end{array}$ & $\begin{array}{l}\text { Postural } \\
\text { BP drop } \\
\text { ( } \mathbf{m m ~ H g})\end{array}$ \\
\hline \multirow{3}{*}{$\begin{array}{l}\text { Normal Control } \\
\text { (Gp I) } \\
\text { AIP in Acute } \\
\text { Attacks (Gp II) } \\
\text { AIP in Remission } \\
\text { (Gp III) } \\
\text { Latent AIP (Gp IV) }\end{array}$} & 28 & $24 \cdot 7 \pm 5 \cdot 8$ & $70 \pm 4$ & $1.72 \pm 0.45$ & $1.27 \pm 0.13$ & $28 \cdot 8 \pm 7 \cdot 4$ & $37 \pm 12$ & $5 \pm 8$ \\
\hline & 8 & $27 \cdot 8 \pm 4 \cdot 6$ & $91 \pm 15 \dagger$ & $1 \cdot 38 \pm 0.23^{*}$ & $1.04 \pm 0.20 \dagger$ & $16 \cdot 5 \pm 4 \cdot 1 \dagger$ & $16 \pm 8 \dagger$ & $8 \pm 6$ \\
\hline & $\begin{array}{l}14 \\
10\end{array}$ & $\begin{array}{l}27 \cdot 2 \pm 6 \cdot 4 \\
21 \cdot 2 \pm 2 \cdot 4\end{array}$ & $\begin{array}{l}72 \pm 5 \\
73 \pm 4\end{array}$ & $\begin{array}{l}1.69 \pm 0.39 \\
1.36 \pm 0.18^{*}\end{array}$ & $\begin{array}{l}1.23 \pm 0.17 \\
1.22 \pm 0.09\end{array}$ & $\begin{array}{l}21 \cdot 6 \pm 5 \cdot 8^{*} \\
27 \cdot 0 \pm 7 \cdot 2\end{array}$ & $\begin{array}{l}31 \pm 12 \\
34 \pm 14\end{array}$ & $\begin{array}{l}3 \pm 8 \\
4 \pm 7\end{array}$ \\
\hline
\end{tabular}

Values $=$ mean $\pm S D .{ }^{*} p<0.05 . \dagger p<0.001 . \ddagger$ difference in diastolic blood pressure.

trols (group I). The differences during the acute attack were most marked in the heart-rate response to standing (30:15 ratio) and the blood pressure response to sustained hand-grip (figs 1 and 2). It is interesting to note that all these abnormal tests improved on subsequent re-testing during remission.

The Valsalva manoeuvre and heart-rate variation during deep breathing were also significantly reduced for the latent porphyrics (group IV) and those in remission (group III) respectively.

\section{Discussion}

The battery of cardiovascular reflex tests used in our study has already proved to be useful in the overall assessment of the autonomic system in diabetic patients in relation to a better understanding of the natural history and prognosis of that disease. ${ }^{1814}$ These tests have now provided objective evidence for the common occurrence of both parasympathetic and sympathetic dysfunction during the severe acute attacks of acute intermittent porphyria as indicated by its clinical manifestations. In contrast to diabetic neuropathy in which neurological damage tends to persist once detectable 1820 the autonomic distur- bance in the acute attack of porphyria appears to be mostly reversible. Interestingly one of the patients in group II experienced a prolonged attack lasting several months and her autonomic tests were repeatedly found to be grossly abnormal. Undoubtedly persistent peripheral nerve damage can occur in porphyric neuropathy, even after a single severe acute attack. ${ }^{2122}$ But the reversible nature of the abnormal tests supports the possibility of a transient functional autonomic blockade either resulting from impaired haem biosynthesis within the nerve cells or an accumulation of porphyrin precursors or their derivatives in the body; the actual operative mechanism however remains speculative..$^{23}$ The cytochrome molecule requires haem as an essential prosthetic group for it to function. Cytochromes not only play an important role in the electron-transport system of respiration but also in the microsomal mixed-function oxidase systems responsible for dehydroxylation and detoxification of numerous compounds of endogenous or exogenous origin. ${ }^{24}$ On the other hand, administration of the porphyrin precursor, ALA, to rodents has been shown to induce abnormal behavioural changes. ${ }^{25}$ ALA has also been reported to affect neuromuscular function in a variety of ways in different types of in vitro 


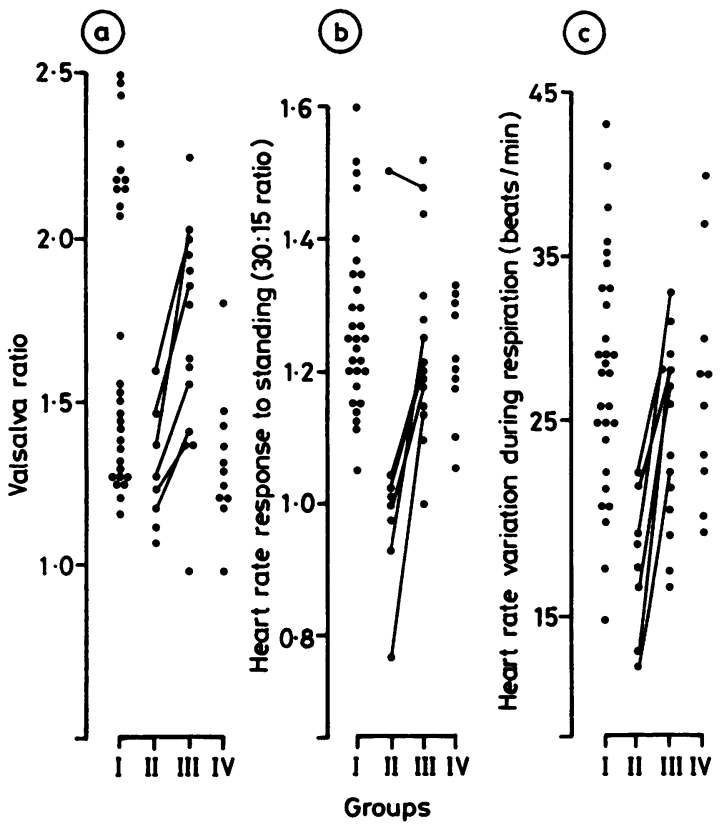

Fig 1 Results of (a) Valsalva manoeuvre; (b) 30:15 ratio and $(c)$ heart rate variation during respiration in different groups: (I) young normal subjects; (II) acute intermittent porphyria in acute attack; (III) acute intermittent porphyria in remission; and (IV) latent acute intermittent porphyria. Each line represents individual patients tested during an acute attack and during remission.

tissue and organ preparations..$^{26-28}$ In all such experiments the ALA concentrations required were several times higher than that measured in the cerebrospinal fluid of patients suffering from an acute attack. In this context however it is noteworthy that Becker et al reported that brain tissue preparations could concentrate ALA when added to the surrounding medium. ${ }^{24}$

The Valsalva manoeuvre has been previously reported to be a good indicator of parasympathetic dysfunction in diabetic patients, and in this study was found to be abnormal in latent acute intermittent porphyria. This observation is in keeping with the subclinical sensorimotor neuropathy often present in these latent acute intermittent porphyria cases as detected by nerve conduction studies. ${ }^{30}$ Yet the Valsalva manoeuvre remained normal in the acute intermittent porphyria patients in remission whereas heart-rate variation during deep breathing was significantly reduced. The discrepancy between these two tests of parasympathetic function could perhaps be accounted for by the relatively small number of patients studied since heart-rate variation

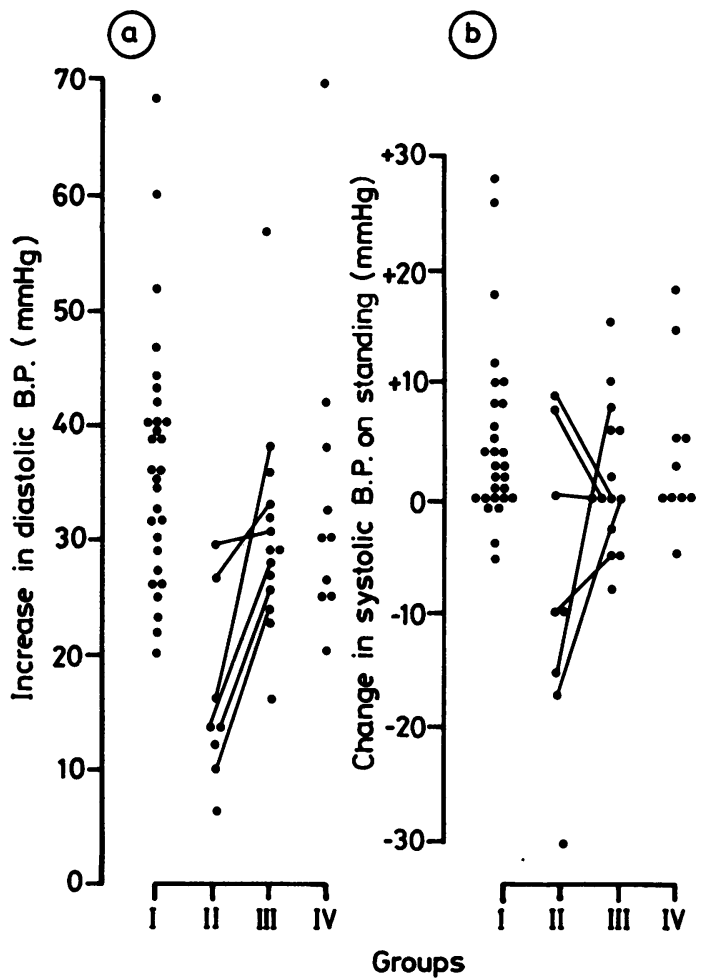

Fig 2 Results of blood pressure response to $(d)$ sustained muscular exercise and (e) posture in groups I to IV.

during deep breathing is reputedly another sensitive index of parasympathetic nerve damage in diabetic patients, often preceding the manifestation of autonomic symptoms for years. ${ }^{31}$ Recently Gupta $e t a^{32}$ reported that the $30: 15$ ratio was also abnormal in asymptomatic Indian subjects with acute intermittent porphyria, but they did not measure other parameters of autonomic function. Nevertheless with cardiac autonomic involvement, these studies have shown that in acute intermittent porphyria as in diabetes, the parasympathetic tests become abnormal earlier and more frequently so than the sympathetic tests. ${ }^{14} 33$

Although the results of the autonomic tests in the groups of porphyric subjects were statistically different from the control group, few individual values were in the unequivocally abnormal range of values published by Ewing et $a^{1011}$ on the basis of their work in diabetic patients. The reason for this is not clear. A higher basal heart rate, as noted in acute intermittent porphyria patients in an acute attack, is presumably not the predominant causative factor since the beat-to-beat variation in heart rate with 
respiration has at least been shown to be independent of basal heart rate. ${ }^{34}$ Care was taken to exclude older subjects from the study since increasing age affects sinus arrhythmia ${ }^{35}$ postural blood pressure,${ }^{36}$ and heart-rate response to the Valsalva manoeuvre. ${ }^{37}$ The complete absence of symptoms in the latent cases with early parasympathetic damage, and the lack of other autonomic clinical manifestations in a number of acute intermittent porphyria patients with severe abdominal pain suggest that the abdominal pain may not entirely be due to autonomic dysfunction. It is possible that the pain may be causally related to the local vasoconstrictor ${ }^{38}$ or spasmodic effects $^{28}$ of the porphyrin precursors (or derivatives) on the gut. Alternatively the experience of pain by some patients with autonomic dysfunction may be due to as yet unidentified idiosyncratic factors, in a way analogous to the manifestation of angina pectoris in patients with ischaemic heart disease where symptoms are often absent despite demonstrable cardiac ischaemia. Until splanchnic autonomic function can be measured by more direct and sensitive methods in porphyric patients its relationship to abdominal pain will remain conjectural; so far, indirect measurement by cardiovascular reflex tests, as employed in this study, has been of limited value.

We thank Dr D Ewing, Royal Infirmary, Edinburgh for his valuable help and advice in setting up the autonomic function tests; and Dr E Bunting for help in carrying out the tests.

\section{References}

' Strand LJ, Meyer UA, Felsher BF, Redecker AG, Marver HS. Decreased red cell uroporphyrinogen I synthetase activity in acute intermittent porphyria. $J$ Clin Invest 1972;51:2530-6.

${ }^{2}$ Granick S, Sassa S, Granick JL, Levere RD, Kappas A. Assays for porphyrins, delta-aminolaevulinic acid dehydratase, and porphobilinogen synthetase in microliter samples of whole blood: applications to metabolic defects involving the heme pathway. Proc Natl Acad Sci (USA) 1972;69:2381-5.

${ }^{3}$ Gibson JB, Goldberg A. The neuropathology of acute porphyria. J Path Bacteriol 1956;71:495-509.

${ }^{4}$ Becker DM, Kramer S. The neurological manifestations of porphyria: a review. Medicine (Baltimore) 1977; 56:411-23.

${ }^{5}$ Goldberg A, Rimington A. Diseases of Porphyrin Metabolism. Springfield, Charles C Thomas 1962:64-109.

- Berlin L, Cotton R. Gastro-intestinal manifestations of porphyria. Am J Digest Dis 1950;17:110-14.

${ }^{7}$ Stein JA, Tschudy DP. Acute intermittent porphyria: A clinical and biochemical study of 46 patients. Medicine (Baltimore) 1970;49:1-16.

${ }^{8}$ Ridley A, Hierons R, Cavanagh JB. Tachycardia and the neuropathy of porphyria. Lancet 1968;ii:708-10.

${ }^{4}$ Kezdi P. Neurogenic hypertension in man in porphyria. Arch Int Med 1954;94:122-30.

${ }^{10}$ Ewing DJ. Cardiovascular reflexes and autonomic neuropathy. Clin Sci Mol Med 1978;55:321-7.

"Ewing DJ. Practical bedside investigation of diabetic autonomic function. In: Sir Roger Bannister, ed. Autonomic failure-A textbook of Clinical Disorders of the Autonomic Nervous System. Oxford: Oxford University Press 1984:371-405.

12 McColl KEL, Moore MR, Thompson GG, Goldberg A. Screening for latent acute intermittent porphyria: the value of measuring both delta-aminolaevulinic acid synthase and uroporphyrinogen-1-synthase activities. J Med Genet 1982:271-2.

${ }^{13}$ Moore MR. Laboratory investigation of disturbances of porphyrin metabolism. Quantitative determination of porphobilinogen and porphyrins in urine and porphyrins in faeces and erythrocytes. In: Broadsheet 109 (Revised Broadsheet 70) Association of Clinical Pathologists (Great Britain). July 1983.

14 Mauzerall D, Granick S. The occurrence and determination of delta-aminolaevulinic acid and porphobilinogen in urine. J Biol Chem 1956;219:435-46.

is Moore MR, Thompson GG, Goldberg A, Ippen H, Seubert A, Seubert S. The biosynthesis of haem in congenital (erythropoietic) porphyria. Int J Biochem 1978;9:933-8.

${ }^{16}$ Ewing DJ, Hume L, Campbell IW, Murray A, Neilson JMM, Clarke BF. Autonomic mechanisms in the initial heart rate response to standing. J Appl Physiol 1980;49:809-14.

${ }^{17}$ Hilsted J, Jensen SB. A simple test for autonomic neuropathy in juvenile diabetics. Acta Med Scand 1979;205:385-7.

${ }^{18}$ Ewing DJ, Campbell IW, Clarke BF. The natural history of diabetic autonomic neuropathy. $Q J$ Med 1980;49:95-108.

14 Ewing DJ, Campbell IW, Clarke BF. Assessment of cardiovascular effects in diabetic autonomic neuropathy and prognostic implication. Ann Intern Med 1980;02:308-11.

${ }^{20}$ Watkins PJ, Edmonds ME. Clinical presentation of diabetic autonomic failure. In: Sir Roger Bannister, ed. Autonomic Failure. A Textbook of Clinical Disorders of the Autonomic Nervous System. Oxford: Oxford University Press. 1984:337-70.

2' Sorensen AWS, With TK. Persistent paresis after porphyric attacks. S Afr J Lab Clin Med 1971;17:101-3.

22 Ridley A. The neuropathy of acute intermittent porphyria. $Q J$ Med 1969;38:708-10.

${ }^{23}$ Yeung Laiwah AC, Goldberg A, Moore MR. Pathogenesis and treatment of acute intermittent porphyria: discussion paper. $J \quad R$ Soc $M e d$ 1983;76:386-92.

${ }^{24}$ Maines MD. New development in the regulation of heme metabolism and their implication. In: L Goldberg, ed. Critical Reviews in Toxicology. Florida: CRC Press Inc. 1984;12:241-313.

${ }^{2 s}$ Cutler MG, Moore MR, Ewart FG. Effects of deltaaminolaevulinic acid administration on social behaviour in the laboratory mice. Psychopharmacol- 
ogy 1979;61:131-5.

${ }^{26}$ Loots JM, Becker DM, Meyer BJ, Goldstruck N, Kramer S. The effect of porphyrin precursors on monosynoptic reflex activity in the isolated hemisected frog spinal cord. J Neurol Transm 1975;36:71-81.

${ }^{27}$ Brennan MJW, Cantrill RC, Kramer S. Effect of deltaaminolaevulinic acid on GABA receptor binding in synaptic plasma membranes. Int $J$ Biochem 1980;12:833-5.

${ }^{28}$ Cutler MG, Moore MR, Dick JM. Effects of deltaaminolaevulinic acid on contractile activity of rabbit duodenum. Europ J Pharmacol 1980;64:221-30.

${ }^{24}$ Becker DM, Kramer S, Viljoen JD. Deltaaminolaevulinic acid uptake by rabbit brain cerebral cortex. J Neurochem 1974; 23:1019-23.

${ }^{30}$ Mustajoki P, Sappalainen AM. Neuropathy in latent hereditary hepatic porphyria. Br Med J 1975;2:310-2.

${ }^{31}$ Mackay JD, Page MM, Cambridge J, Watkins PJ. Diabetic autonomic neuropathy. The diagnostic value of heart rate monitoring. Diabetologia 1980;18:471-8.
${ }^{32}$ Gupta GL, Saksena HC, Gupta BD. Cardiac dysautonomia in acute intermittent porphyria. Ind $J$ Med Res 1983;78:253-6.

${ }^{33}$ Bennet T, Farquhar IK, Hosking DJ, Hampton JR. Assessment of methods for estimating autonomic nervous control of the heart in patients with diabetes mellitus. Diabetes 1978;27:1167-74.

${ }^{34}$ Ewing DJ, Borsey DQ, Bellavere F, Clarke BF. Cardiac autonomic neuropathy in diabetes: comparison of measures of R-R interval variation. Diabetologia 1981;21:18-24.

${ }^{35}$ Hellman JB, Stacy RW. Variation of respiratory sinus arrhythmia with age. J Appl Physiol 1976;41:734-8.

${ }^{36}$ Caird FI, Andrews GR, Kennedy RD. Effect of posture on blood pressure in the elderly. Br Heart $J$ 1973;35: 527-30.

${ }^{37}$ Kalbfleisch JH, Stowe DF, Smith JJ. Evaluation of the heart rate response to the Valsalva manoeuvre. Am Heart J 1978;95:705-15.

${ }^{38}$ Denny Brown D, Sciarra D. Changes in the nervous system in acute porphyria. Brain 1945;68:1-16. 